\title{
RESPON TANAMAN KARET DI PEMBIBITAN TERHADAP PEMBERIAN PUPUK MAJEMUK MAGNESIUM PLUS
}

\author{
The Response of Rubber Plant in Nursery to the Provison of Magnesium Plus \\ Compound Fertilizer \\ Saiful Rodhian ACHMAD*) dan Riko Cahya PUTRA \\ Balai Penelitian Getas, Pusat Penelitian Karet \\ Jl. Pattimura KM 6 Salatiga Jawa tengah \\ Email: sai_8988@yahoo.com
}

Diterima : 26 Oktober 2015 / Direvisi : 14 Juli 2016 / Disetujui : 11 Agustus 2016

\begin{abstract}
The optimum fertilization can shorten the period of the rubber plant in nursery. Scarcity and high cost of inorganic fertilizer for the rubber nursery has occurred. This research aimed at investigating the response of rubber nursery to the Magnesium plus compound fertilizer. This research was conducted at the Getas Research Center field trials, Salatiga, Central Java. The study design used Randomized Completely Block Design with six treatments and ten replications. The treatments consist of: 1) control (without fertilization), 2) single fertilizer $N P K+$ dolomite, 3) single fertilizer $N P K+$ Kieserite standard, 4) single fertilizer $N P K+M g$ plus dosage of $75 \%$, 5) single fertilizer NPK + Mg plus dosage of 100\%, and 6) single fertilizer NPK $+M g$ plus dosage of $125 \%$. Parameters measured were plant height, stem diameter, weight of plants, weight of roots, and value of Relative Agronomic Effectiveness (RAE). Observations were made every month for six months. Fertilization with NPK fertilizers combined with various Magnesium plus compound fertilizer could increase plant height, trunk diameter, plant wet weight, root wet and dry weight, compared to single fertilizer $N P K+$ Kieserite standar treatment and control. Agronomic value of treatment NPK fertilizers combined Magnesium plus compound fertilizer dosage of $125 \%$ showed the best results compared with other treatments.
\end{abstract}

Keywords: Rubber plant; nursery; Magnesium plus compound fertilizer.
Abstrak

Masa tanaman karet di pembibitan dapat dipersingkat dengan cara pemupukan yang optimum. Saat ini banyak terjadi kelangkaan dan mahalnya pupuk anorganik untuk pembibitan karet. Penelitian ini bertujuan untuk mengetahui respon tanaman karet di pembibitan terhadap pupuk majemuk Magnesium plus. Penelitian aplikasi pupuk majemuk Magnesium plus dilakukan di lahan percobaan Balai Penelitian Getas, Salatiga, Jawa Tengah. Rancangan penelitian ini menggunakan Rancangan Acak Kelompok Lengkap terdiri atas enam perlakuan dengan sepuluh ulangan. Perlakuan terdiri atas: 1) kontrol (tanpa pemupukan), 2) pupuk tunggal NPK+Dolomite, 3) pupuk tunggal NPK+Kieserite standar, 4) pupuk tunggal NPK + pupuk majemuk Magnesium plus dosis $75 \%$, 5) pupuk tunggal NPK + pupuk majemuk Magnesium plus dosis $100 \%$, dan 6) pupuk tunggal NPK + pupuk majemuk Magnesium plus dosis $125 \%$. Parameter yang diamati: tinggi tanaman, diameter batang, bobot tanaman dan akar, kandungan hara daun serta nilai Relative Agronomic Effectiveness (RAE). Pengamatan dilakukan setiap satu bulan sekali selama enam bulan. Pemupukan dengan pupuk tunggal NPK yang dikombinasikan dengan berbagai tingkatan dosis pupuk majemuk Magnesium plus dapat meningkatkan tinggi tanaman, diameter batang, bobot basah tanaman, serta bobot basah dan kering akar dibandingkan dengan perlakuan pupuk tunggal NPK+Kieserite standar dan kontrol tanpa pupuk. Secara agronomis perlakuan pupuk tunggal NPK dikombinasikan pupuk majemuk Magnesium plus dengan tingkatan 
dosis $125 \%$ menunjukkan hasil yang paling tinggi dibandingkan dengan perlakuan lain.

Kata kunci: Tanaman karet; pembibitan; pupuk majemuk Magnesium plus.

\section{PENDAHULUAN}

Karet merupakan salah satu komoditas pertanian yang penting baik untuk lingkup nasional maupun internasional. Menurut Boerhendy (2009), fungsi ekonomi yang menonjol dari komoditas karet adalah sebagai sumber pendapatan lebih dari 10 juta petani dan menyerap sekitar 1,7 juta tenaga kerja, serta memberikan kontribusi yang sangat berarti sebagai penyumbang devisa negara. Masalah usahatani karet yang dihadapi petani secara umum adalah keterbatasan modal baik untuk membeli bibit unggul maupun sarana produksi lain seperti herbisida dan pupuk. Selain itu ketersediaan sarana produksi pertanian tersebut di tingkat petani juga masih terbatas. Dalam rangka meningkatkan ekspor komoditas karet, pemerintah telah mengambil kebijakan untuk meningkatkan produktivitas karet melalui peremajaan maupun perluasan lahan yang sesuai serta dengan menggunakan bibit okulasi klon anjuran (Meihana \& Rusidi, 2013).

Peningkatan luas areal perkebunan karet menyebabkan diperlukannya ketersediaan bibit karet dalam jumlah besar. Bibit karet yang baik diperoleh melalui pemeliharaan yang intensif terutama pemupukan. Pemupukan merupakan faktor penentu utama, khususnya keseimbangan dosis dan jenis pupuk yang digunakan dan bukan pada tingkat dosis yang tinggi (Wachjar \& Kadarisman, 2007). Pemupukan dalam budidaya tanaman karet membutuhkan biaya yang cukup besar setelah biaya penyadapan. Pemupukan yang efektif akan memberikan dampak positif bagi tanaman dan tentunya juga pada efisiensi biaya (Nugroho, 2009). Pada umumnya tanah subur atau top soil sering digunakan untuk media pembibitan dan sebagian besar telah dimanfaatkan dan ketersediaannya semakin menurun sehingga harus menggunakan jenis tanah lain yang kurang subur (Sianipar, Saputra, \& Puspita, 2014).
Masalah yang dihadapi pada tanah yang kurang subur yaitu $\mathrm{pH}$ masam dan kandungan bahan organik rendah, miskin hara Kalium (K), Kalsium (Ca) dan Magnesium (Mg) serta kahat unsur hara mikro. Untuk mengatasi media tanah yang kurang subur dapat diperbaiki dengan menambahkan pupuk dan atau dengan menambahkan bahan campuran ke dalam media.

Tanaman dapat tumbuh dengan baik dan menghasilkan produksi yang tinggi diperlukan unsur hara dalam kondisi yang cukup dan harus berada dalam suatu keseimbangan. Unsur hara yang sering mendapat perhatian serius karena kurang dan lambat tersedia dalam tanah adalah unsur $\mathrm{N}, \mathrm{P}, \mathrm{Ca}, \mathrm{Mg}, \mathrm{S}$, dan $\mathrm{P}$. Unsur hara paling utama yang dibutuhkan oleh tanaman adalah $\mathrm{N}, \mathrm{P}, \mathrm{K}$ yang biasanya diberikan sebagai pupuk, $\mathrm{Ca}$ dan $\mathrm{Mg}$ diberikan sebagai kapur dan $\mathrm{S}$ diberikan sebagai tepung belerang. Selain hara makro, hara mikro juga diperlukan tanaman untuk pertumbuhan walaupun dibutuhkan dalam jumlah sedikit. Seng $(\mathrm{Zn})$ dan tembaga $(\mathrm{Cu})$ berperan penting dalam aktivitas enzim (Reuther, 1957). Pemberian hara mikro juga mampu meningkatkan pertumbuhan tanaman karet. Penelitian yang dilakukan oleh Nurjaya (2010) menunjukkan bahwa pemberian pupuk NPK dikombinasikan dengan pupuk mikro majemuk dosis 2 $\mathrm{g} /$ pohon dapat meningkatkan pertumbuhan tinggi, dan diameter batang tanaman karet di pembibitan.

Penanaman pada tanah-tanah yang defisit unsur hara N, P, K, Ca, Mg dan tanah masam akan menghasilkan pertumbuhan tanaman karet kurang baik. Oleh karena itu perlu diberikan masukan sesuai dengan kebutuhan tanaman (Suwandi, 2008). Upaya yang dapat dilakukan untuk memenuhi kebutuhan $\mathrm{Ca}$ dan $\mathrm{Mg}$ pada tanah maupun tanaman yaitu dengan memberikan pupuk dolomite atau pemberian pupuk $\mathrm{Ca}$ dan $\mathrm{Mg}$. Menurut Maulana (2012), dolomite adalah mineral yang berasal dari alam yang mengandung unsur hara Magnesium dan Kalsium berbentuk tepung dengan rumus kimia $\mathrm{CaMg}\left(\mathrm{CO}_{3}\right)_{2}$ (Maulana, 2012). Syarat mutu pupuk dolomite sesuai dengan SNI 02-28042005 memiliki kandungan minimal $\mathrm{CaO}$ dan MgO masing-masing adalah 29\% dan 18\%. 
Kalsium dan Magnesium merupakan hara makro sekunder. Kalsium berperan sebagai nutrisi tanaman yang diperlukan untuk pertumbuhan dan perkembangan khususnya akar dan tunas (Tuteja \& Mahajan, 2007). Gejala tanaman kekurangan $\mathrm{Ca}$ yaitu terhambatnya pertumbuhan pucuk (titik tumbuh), kemudian pertumbuhan tanaman kerdil dan mati (Baker \& Pilbean, 2006). Magnesium dibutuhkan dalam aktivasi enzim-enzim dan sebagai atom pusat dari molekul klorofil. Magnesium mengaktifkan enzim ribulose 1,5-bisphosphate (RuBP) carboxylase yang penting dalam proses fotosintesis (Cakmak \& Yazici, 2010; Yang et al., 2012; Gransee \& Fuhrs, 2013). Aplikasi Nitrogen (N) dan Potasium (K) dalam tanah tanpa pemberian Mg dapat menyebabkan defisiensi Magnesium (khlorosis).

Unsur hara mikro seperti B, Cu, Mn dan Fe, memiliki peran penting bagi pertumbuhan tanaman karet, antara lain sebagai pembentuk enzim dan penyusunan protein dalam proses metabolisme selama masa TBM. Defisiensi unsur mikro dapat menyebabkan pertumbuhan tanaman karet terhambat khususnya pada masa TBM dan menurunkan produksi pada TM (Stevanus, Saputra, \& Wijaya, 2015)

Penelitian ini bertujuan untuk mengetahui pengaruh pemberian pupuk majemuk Magnesium plus terhadap pertumbuhan tanaman karet di pembibitan.

\section{BAHAN DAN METODE}

Penelitian dilakukan di lahan percobaan Balai Penelitian Getas, Salatiga, Jawa Tengah. Pelaksanaan penelitian dilakukan pada bulan Januari sampai dengan Desember 2014. Tanaman indikator yang digunakan adalah bibit karet klon PR 303 yang berumur 2 bulan. Jenis tanah yang digunakan adalah tanah Inceptisols yang dimasukkan ke dalam polibeg sebanyak $8 \mathrm{~kg}$ dengan ukuran polibeg $30 \mathrm{~cm} \mathrm{x} 40 \mathrm{~cm}$. Pupuk yang digunakan adalah pupuk tunggal NPK standar/konvensional (Urea, $\mathrm{SP}-36, \mathrm{KCl})$, Kieserite $\left(\mathrm{MgSO}_{4} 7 \mathrm{H}_{2} \mathrm{O}\right)$ kandungan MgO: 27\%, pupuk Dolomite $\left(\mathrm{CaMg}\left(\mathrm{CO}_{3}\right)_{2}\right)$ kandungan $\mathrm{MgO}: 18 \%$ dan pupuk majemuk Magnesium Plus. Pupuk majemuk Magnesium Plus mikro merupakan pupuk Magnesium yang berbahan dasar Dolomite dan dicampur dengan unsur mikro dengan komposisi kandungan hara yaitu 18,83\% MgO, 30,12\% $\mathrm{CaO}$ dan unsur mikro 0,20\% $\mathrm{MnO} ; 0,25 \%$ $\mathrm{CuO} ; 0,30 \% \mathrm{~B}_{2} \mathrm{O}_{3} ; 0,20 \% \mathrm{ZnO}$ dan $0,05 \%$ $\mathrm{Fe}_{2} \mathrm{O}_{5}$ (total mikro: 1\%).

Rancangan penelitian yang digunakan adalah Rancangan Acak Kelompok Lengkap (Randomize Completely Block Design), terdiri atas enam perlakuan dengan setiap perlakuan diulang sepuluh kali ulangan. Perlakuan tingkat dosis pupuk majemuk Magnesium plus yang diberikan atas dasar dosis pemakaian Kieserite. Perlakuan terdiri atas: 1) Kontrol (perlakuan tanpa pupuk), 2) pupuk tunggal NPK+ Dolomite $(100 \%), 3)$ pupuk tunggal NPK+ Kieserite standar, 4) pupuk tunggal NPK+ $75 \%$ dosis pupuk Mg Plus mikro 1\%, 5) pupuk tunggal NPK $+100 \%$ dosis pupuk $\mathrm{Mg}$ Plus mikro 1\%, dan 6) pupuk tunggal NPK+ 125\% dosis pupuk Mg Plus mikro 1\%. Pupuk dosis rekomendasi pupuk tunggal disajikan pada Tabel 1 dan dosis perlakuan pemupukan Magnesium plus disajikan pada Tabel 2 .

Pupuk Urea, SP-36, KCl dan Kieserite diberikan sebagai pupuk dasar atau standar, sedangkan pupuk majemuk Magnesium plus mikro sebagai pupuk yang diuji pemberiannya disesuaikan dengan lamanya waktu pengujian. Pemupukan Urea, SP-36, KCl, Dolomite, Kieserite, dan majemuk Magnesium plus diberikan satu bulan sekali. Pupuk dasar dan pupuk majemuk Magnesium plus diberikan dengan cara ditugal di samping tanaman dengan jarak $5 \mathrm{~cm}$ dari pangkal batang dengan kedalaman $\pm 5 \mathrm{~cm}$.

Pengamatan pertumbuhan tanaman dilakukan setiap bulan sekali selama enam bulan. Parameter pertumbuhan yang diamati terdiri atas : (1) tinggi tanaman dengan cara mengukur tanaman dari bagian tanaman diatas tanah sampai ujung titik tumbuh bagian atas yang berbentuk seperti huruf "V" menggunakan meteran, (2) diameter batang di ukur dari bagian tanaman di atas tanah dengan ketinggian 10 $\mathrm{cm}$ menggunakan digital microcaliper dan (3) bobot basah (daun, batang, akar) ditimbang dengan menggunakan timbangan analitik, sedangkan bobot kering dioven 
Tabel 1. Rekomendasi umum dosis pupuk tunggal NPK tanaman karet di pembibitan batang bawah polibeg

Table1. Recommendation dosage of single fertilizer rubber plants in the nursery rootstock polybag

\begin{tabular}{|c|c|c|c|c|}
\hline \multirow{2}{*}{$\begin{array}{c}\text { Umur } \\
\text { (bulan) } \\
\text { Age } \\
\text { (months) }\end{array}$} & \multicolumn{3}{|c|}{$\begin{array}{l}\text { Dosis pupuk tunggal (g/pohon) } \\
\text { Single fertilizer dosage (g/tree) }\end{array}$} & \multirow{2}{*}{$\begin{array}{l}\text { Frekuensi pemupukan (kali/bulan) } \\
\text { Fertilization frequency (times/month) }\end{array}$} \\
\hline & Urea & SP-36 & $\mathrm{Kcl}$ & \\
\hline 2 & 5 & 4 & 2 & 1 \\
\hline 3 & 5 & 4 & 2 & 1 \\
\hline 4 & 5 & 4 & 5 & 1 \\
\hline 5 & 10 & 5 & 5 & 1 \\
\hline 6 & 10 & 5 & 10 & 1 \\
\hline 7 & 10 & 5 & 10 & 1 \\
\hline
\end{tabular}

Tabel 2. Perlakuan takaran pupuk uji efektivitas pupuk majemuk Magnesium plus untuk tanaman karet di pembibitan batang bawah polibeg

Table 2. Treatment effectiveness test of Magnesium plus compound fertilizer to rubber plants in the nursery rootstock polybag

\begin{tabular}{|c|c|c|c|c|c|c|}
\hline \multirow{2}{*}{$\begin{array}{c}\text { Umur } \\
\text { (Bulan) } \\
\text { Age } \\
\text { (Months) }\end{array}$} & \multirow{2}{*}{$\begin{array}{c}\text { Kontrol } \\
\text { Control }\end{array}$} & \multicolumn{5}{|c|}{$\begin{array}{l}\text { Perlakuan ( } \mathrm{g} / \text { pohon/bulan) } \\
\text { Treatment ( } \mathrm{g} / \text { tree/months })\end{array}$} \\
\hline & & $\begin{array}{c}(1) \\
\text { NPK+ } \\
\text { Dolomite }\end{array}$ & $\begin{array}{c}(2) \\
\text { NPK+ } \\
\text { Kieserite }\end{array}$ & $\begin{array}{c}(3) \\
\text { NPK+ } \\
\text { Mg Plus } \\
75 \%\end{array}$ & $\begin{array}{c}(4) \\
\text { NPK+ } \\
\text { Mg Plus } \\
100 \%\end{array}$ & $\begin{array}{c}(5) \\
\text { NPK+ } \\
\text { Mg Plus } \\
125 \%\end{array}$ \\
\hline 2 & 0 & 1,5 & 1 & 1 & 1,5 & 2 \\
\hline 3 & 0 & 3 & 2 & 2,5 & 3 & 3,5 \\
\hline 4 & 0 & 3 & 2 & 2,5 & 3 & 3,5 \\
\hline 5 & 0 & 3 & 2 & 2,5 & 3 & 3,5 \\
\hline 6 & 0 & 3 & 2 & 2,5 & 3 & 3,5 \\
\hline 7 & 0 & 3 & 2 & 2,5 & 3 & 3,5 \\
\hline
\end{tabular}

pada suhu $105^{\circ} \mathrm{C}$ selama 24 jam. Sifat kimia dan fisika tanah atau media tanam dianalisis terdiri atas : tekstur 3 fraksi, $\mathrm{pH}$ ekstrak $\mathrm{H} 2 \mathrm{O}$; C-organik dan N; $\mathrm{P}$ tersedia Bray 1; nilai tukar kation $\mathrm{Ca}, \mathrm{Mg}, \mathrm{K}$ dan $\mathrm{Na}$ ekstrak NH4-Ac 1N pH7; dan kapasitas tukar kation (KTK). Untuk mengetahui status hara daun dilakukan pengambilan contoh daun yang sudah dorman pada payung kedua dan di analisa daun terdiri atas : N, P, Ca, Mg, K-Total tanaman.

Untuk mengetahui pengaruh perlakuan, data dianalisis dengan analisis sidik ragam (ANOVA) dan diikuti dengan uji lanjutan menggunakan Duncan Multiple range Test (DMRT) pada taraf 5\% untuk melihat perbedaan antar perlakuan. Untuk mengetahui efektivitas pupuk majemuk Magnesium plus dianalisis dengan Relative Agronomic Effectiveness (RAE) (Machay, Syers, \& Gregg, 1984) dengan rumus sebagai berikut:

$$
\operatorname{RAE}(\%)=\frac{\mathbf{Y p}-\mathbf{Y k}}{\mathbf{Y a}-\mathbf{Y k}} \times 100
$$


Keterangan (Remaks):

RAE : Relative Agronomic Effectiveness (\%)

Yp : hasil yang diperoleh dari aplikasi pupuk yang diuji

Yk : hasil yang diperoleh tanpa pemberian pupuk (perlakuan kontrol)

Ya : hasil yang diperoleh dari aplikasi pupuk acuan (perlakuan standar)

\section{HASIL DAN PEMBAHASAN}

\section{Tekstur dan Sifat Tanah Inceptisols}

Analisa tanah Inceptisols sebelum penelitian memiliki tekstur tanah yaitu tekstur lempungan. Hasil analisis kandungan hara tanah inceptisols sebagai media tanam menunjukkan tingkat kesuburan tanah tergolong rendah disajikan pada Tabel 3. Berdasarkan kriteria kesuburan tanah (Pusat Penelitian Tanah, 1983), hasil analisis laboratorium menunjukan bahwa $\mathrm{pH} \mathrm{H}_{2} \mathrm{O}$ tanah tergolong masam, kadar C-Organik, N-total dan C/N rasio tergolong rendah. Kadar $\mathrm{P}$ tersedia (Bray I) tergolong sangat rendah. Nilai tukar kation Ca-dd, Mg-dd dan Na-dd tergolong rendah, sedangkan $\mathrm{K}$-dd tergolong sedang. Kapasitas tukar kation (KTK) tergolong sedang dengan kejenuhan basa (KB) tergolong rendah. Berdasarkan data hasil analisis laboratorium tanah inceptisols sebagai media tanaman mempunyai permasalahan tingkat kesuburan tanah yang rendah yaitu $\mathrm{pH}$ tanah masam,

Tabel 3. Hasil analisis tanah sebelum penelitian

Table 3. The results of soil analysis before the research

\begin{tabular}{lc}
\hline Jenis penetapan & Hasil penetapan \\
Type of determination & Results of determination \\
\hline Tekstur & Lempungan \\
Pasir (\%) & 13,15 \\
Debu (\%) & 34,10 \\
Lempung (\%) & 52,75 \\
pH H ${ }_{2} \mathrm{O}$ & 5,25 \\
Bahan organik & \\
C (\%) & 0,91 \\
N (\%) & 0,110 \\
C/N & 8,27 \\
P ${ }_{2}$ B Bray I (ppm) & 5,58 \\
Kation dapat ditukar & \\
K (me/100 g) & 0,52 \\
Ca (me/100 g) & 1,25 \\
Mg (me/100 g) & 0,30 \\
Na (me/100g) & 0,10 \\
KTK (me/100 g) & 15,73 \\
KB (\%) & 13,79 \\
\hline
\end{tabular}

Sumber : Laboratorium Balai Penelitian Getas (2014)

Source: Getas Research Center Laboratorium (2014) 
kandungan $\mathrm{C}$-organik dan $\mathrm{N}$-total rendah serta $\mathrm{Ca}$-dd dan $\mathrm{Mg}$-dd tergolong rendah.

Tanah dengan KTK dan kandungan bahan organik yang rendah menyebabkan tingkat efisiensi pemupukan menjadi rendah karena unsur hara kation dalam tanah mudah tercuci dari komplek pertukaran. Tingkat efisiensi pemupukan yang rendah menyebabkan pertumbuhan dan produktivitas tanaman menjadi tidak optimal. Oleh sebab itu, upaya yang diperlukan untuk memperbaiki kesuburan tanah tersebut yaitu melalui pemberian pupuk urea, kalium, fosfat, yang optimal sesuai dengan status hara tanah dan kebutuhan tanaman serta pemberian bahan organik. Selain itu, untuk meningkatkan pertumbuhan dan kualitas hasil pemberian pupuk Magnesium plus sangat diperlukan.

\section{Tinggi Tanaman}

Pada Tabel 4 hasil uji statistik menunjukkan bahwa pada bulan April pemberian pupuk tunggal NPK dikombinasikan dengan pupuk majemuk Magnesium plus tidak berbeda nyata dibandingkan dengan pemberian pupuk tunggal NPK + Kieserite standar dan kontrol tanpa pupuk. Pada bulan Mei hasil uji statistik menunjukkan bahwa pemberian pupuk tunggal NPK dikombinasikan pupuk majemuk Magnesium plus tidak berbeda nyata dibandingkan dengan perlakuan pupuk tunggal NPK + Kieserite standar dan kontrol, kecuali pada pemberian pupuk majemuk Magnesium plus dosis 125\% berbeda nyata dibandingkan perlakuan kontrol. Pertumbuhan tinggi tanaman karet tertinggi $46,87 \mathrm{~cm}$ dicapai pada pemberian pupuk majemuk Magnesium plus dosis $125 \%$. Pada bulan Juni dan Juli hasil uji statistik menunjukkan bahwa secara umum pemberian pupuk tunggal NPK dikombinasikan pupuk majemuk Magnesium plus tidak berbeda nyata dibandingkan dengan perlakuan kontrol tanpa pupuk, kecuali pada pemberian pupuk majemuk Magnesium plus dosis $125 \%$, secara nyata mampu meningkatkan tinggi tanaman dibandingkan dengan perlakuan pupuk tunggal NPK + Kieserite standar dan kontrol.

Pada pengamatan bulan Agustus hasil uji statistik menunjukkan bahwa pemberian pupuk tunggal NPK dikombinasikan pupuk majemuk Magnesium plus secara umum tidak berbeda nyata dibandingkan pemberian pupuk tunggal NPK + Kieserite standar dan pupuk tunggal NPK + Dolomite, tetapi berbeda nyata dibandingkan kontrol. Pada bulan September atau umur 6 bulan setelah tanam (BST) hasil uji statistik menunjukkan bahwa pemberian pupuk tunggal NPK dikombinasikan pupuk majemuk Magnesium plus berbeda nyata dibandingkan pupuk tunggal NPK + Dolomite dan kontrol, tetapi tidak berbeda nyata dengan pemberian pupuk tunggal NPK

Tabel 4. Data tinggi tanaman karet sebagai respon terhadap berbagai perlakuan pupuk majemuk Magnesium plus

Table 4. Data of rubber plant height as a response to various treatments Magnesium plus compound fertilizer

\begin{tabular}{lrrrrrr}
\hline \multicolumn{1}{c}{$\begin{array}{c}\text { Perlakuan } \\
\text { Treatment }\end{array}$} & \multicolumn{5}{c}{$\begin{array}{c}\text { Tinggi tanaman } \\
\text { Plant height } \\
\text { (cm) }\end{array}$} \\
\cline { 2 - 8 } & $5 \mathrm{Apr}$ & $7 \mathrm{Mei}$ & $6 \mathrm{Jun}$ & $5 \mathrm{Jul}$ & $6 \mathrm{Agst}$ & $7 \mathrm{Sep}$ \\
\hline Kontrol, tanpa pupuk & $32,20 \mathrm{a}$ & $40,19 \mathrm{a}$ & $48,19 \mathrm{a}$ & $58,77 \mathrm{a}$ & $64,78 \mathrm{a}$ & $71,42 \mathrm{a}$ \\
Pupuk tunggal NPK + Dolomite & $32,69 \mathrm{a}$ & $41,36 \mathrm{ab}$ & $50,46 \mathrm{ab}$ & $60,11 \mathrm{a}$ & $75,23 \mathrm{~b}$ & $82,25 \mathrm{~b}$ \\
Pupuk tunggal NPK + Kieserite Standar & $32,64 \mathrm{a}$ & $43,48 \mathrm{ab}$ & $53,77 \mathrm{ab}$ & $64,17 \mathrm{ab}$ & $81,36 \mathrm{~b}$ & $90,78 \mathrm{bc}$ \\
Pupuk tunggal NPK + pupuk Mg plus 75\% & $33,30 \mathrm{a}$ & $43,54 \mathrm{ab}$ & $53,46 \mathrm{ab}$ & $64,16 \mathrm{ab}$ & $81,55 \mathrm{~b}$ & $90,12 \mathrm{bc}$ \\
Pupuk tunggal NPK + pupuk Mg plus 100\% & $33,20 \mathrm{a}$ & $44,12 \mathrm{ab}$ & $53,85 \mathrm{ab}$ & $65,30 \mathrm{ab}$ & $81,88 \mathrm{~b}$ & $92,05 \mathrm{c}$ \\
Pupuk tunggal NPK + pupuk Mg plus 125\% & $32,25 \mathrm{a}$ & $46,87 \mathrm{~b}$ & $56,29 \mathrm{~b}$ & $68,64 \mathrm{~b}$ & $83,20 \mathrm{~b}$ & $92,96 \mathrm{c}$ \\
\hline
\end{tabular}

Angka yang diikuti huruf yang sama pada kolom sama menunjukkan tidak berbeda nyata pada taraf $a<$ 0,05

Number followed by the same letter in the same column were not significantly different a $<0.05$ level 
+ Kieserite standar. Pertumbuhan tinggi tanaman tertinggi mencapai $92,96 \mathrm{~cm}$ pada pemberian pupuk majemuk Magnesium plus dosis $125 \%$. Namun demikian secara kuantitatif pertumbuhan tinggi tanaman cenderung meningkat sejalan dengan penambahan pupuk majemuk Magnesium plus mikro. Hal ini menunjukkan bahwa pupuk tunggal NPK yang dikombinasikan dengan Magnesium plus mampu meningkatkan tinggi tanaman dibandingkan perlakuan pupuk tunggal NPK yang dikombinasikan baik pupuk Kieserite maupun Dolomite. Hasil tersebut sesuai dengan penelitian Nurjaya (2010) yaitu pemberian pupuk NPK dikombinasikan dengan pupuk mikro majemuk berbeda nyata dibandingkan dengan perlakuan pupuk NPK standar dan kontrol terhadap tinggi tanaman. Meskipun kebutuhan tanaman akan hara mikro sedikit tetapi kekahatan unsur ini dapat menghambat pertumbuhan atau mengurangi hasil sebagaimana hara makro.

\section{Diameter Batang}

Berdasarkan hasil uji statistik pada Tabel 5 menunjukkan bahwa pada bulan April pemberian pupuk tunggal NPK dikombinasikan pupuk majemuk Magnesium plus tidak berbeda nyata dibandingkan dengan perlakuan pupuk tunggal NPK + Kieserite standar dan kontrol terhadap diameter batang. Pada bulan Mei hasil uji statistik menunjukkan bahwa pemberian pupuk tunggal NPK dikombinasikan pupuk majemuk Magnesium plus tidak berbeda nyata dibandingkan dengan perlakuan pupuk tunggal NPK + Kieserite standar dan kontrol kecuali pada pemberian pupuk majemuk Magnesium plus dosis $100 \%$ dan $125 \%$, secara nyata meningkatkan diameter batang dibandingkan perlakuan pupuk tunggal NPK + Kieserite standar, pupuk tunggal NPK + Dolomite dan kontrol. Diameter batang tertinggi $3,95 \mathrm{~mm}$ pada pemberian pupuk majemuk Magnesium plus dosis $125 \%$. Hasil uji statistik pada bulan Juni menunjukkan bahwa pemberian pupuk tunggal NPK dikombinasikan pupuk majemuk Magnesium plus tidak berbeda nyata dibandingkan dengan perlakuan pupuk NPK + Kieserite standar dan kontrol. Pada bulan Juli menunjukkan bahwa pemberian pupuk tunggal NPK dikombinasikan pupuk majemuk Magnesium plus berbeda nyata dibandingkan dengan perlakuan kontrol, tetapi tidak berbeda nyata dibandingkan pemberian pupuk tunggal NPK + Kieserite standar. Pada bulan September atau 6 bulan setelah tanam hasil uji statistik menunjukkan bahwa pemberian pupuk tunggal NPK dikombinasikan pupuk majemuk Magnesium plus berbeda nyata dibandingkan dengan perlakuan pupuk tunggal NPK + Dolomite dan kontrol. Namun demikian secara kuantitatif pemberian pupuk majemuk Magnesium plus dapat

Tabel 5. Data diamater batang karet sebagai respon terhadap berbagai perlakuan pupuk majemuk Magnesium plus

Table 5. Data of rubber trunk diameter as response to various treatments Magnesium plus compound fertilizer

\begin{tabular}{lrrrrrr}
\hline \multicolumn{1}{c}{$\begin{array}{c}\text { Perlakuan } \\
\text { Treatment }\end{array}$} & \multicolumn{5}{c}{$\begin{array}{c}\text { Diameter batang } \\
\text { Trunk diameter } \\
\text { (mm) }\end{array}$} \\
\cline { 2 - 8 } & $5 \mathrm{Apr}$ & $7 \mathrm{Mei}$ & $6 \mathrm{Jun}$ & $5 \mathrm{Jul}$ & 6 Agst & $7 \mathrm{Sep}$ \\
\hline Kontrol, tanpa pupuk & $2,60 \mathrm{a}$ & $3,26 \mathrm{a}$ & $4,35 \mathrm{a}$ & $5,32 \mathrm{a}$ & $6,62 \mathrm{a}$ & $7,66 \mathrm{a}$ \\
Pupuk tunggal NPK + Dolomite & $2,95 \mathrm{a}$ & $3,71 \mathrm{ab}$ & $4,66 \mathrm{a}$ & $6,63 \mathrm{~b}$ & $7,12 \mathrm{ab}$ & $8,87 \mathrm{ab}$ \\
Pupuk tunggal NPK + Kieserite Standar & $2,75 \mathrm{a}$ & $3,57 \mathrm{ab}$ & $4,74 \mathrm{a}$ & $6,77 \mathrm{~b}$ & $7,58 \mathrm{ab}$ & $9,45 \mathrm{bc}$ \\
Pupuk tunggal NPK + pupuk Mg plus 75\% & $2,95 \mathrm{a}$ & $3,56 \mathrm{ab}$ & $4,56 \mathrm{a}$ & $6,79 \mathrm{~b}$ & $7,67 \mathrm{ab}$ & $9,13 \mathrm{bc}$ \\
Pupuk tunggal NPK + pupuk Mg plus 100\% & $2,97 \mathrm{a}$ & $3,90 \mathrm{~b}$ & $4,93 \mathrm{a}$ & $6,95 \mathrm{~b}$ & $8,16 \mathrm{~b}$ & $9,79 \mathrm{bc}$ \\
Pupuk tunggal NPK + pupuk Mg plus 125\% & $2,94 \mathrm{a}$ & $3,95 \mathrm{~b}$ & $5,08 \mathrm{a}$ & $7,34 \mathrm{~b}$ & $8,47 \mathrm{~b}$ & $10,45 \mathrm{c}$ \\
\hline
\end{tabular}

Angka yang diikuti huruf yang sama pada kolom sama menunjukkan tidak berbeda nyata pada taraf a < 0,05

Number followed by the same letter in the same column were not significantly different $a<0.05$ level 
meningkatkan diameter batang dibandingkan pupuk tunggal NPK + Kieserite standar dan pupuk tunggal NPK + Dolomite. Pertumbuhan diameter batang bibit tanaman karet umur 1 sampai dengan 6 bulan setelah tanam (BST) terus bertambah sejalan dengan peningkatan dosis pupuk yang diberikan. Pertumbuhan diameter batang terbesar pada umur 1-6 BST masing-masing $2,94 \mathrm{~mm} ; 3,95 \mathrm{~mm}$; $5,08 \mathrm{~mm}, 7,34 \mathrm{~mm} ; 8,47 \mathrm{~mm} ; 10,45 \mathrm{~mm}$ yang dicapai pada pemberian pupuk majemuk Magnesium plus dengan tingkatan dosis $125 \%$.

\section{Bobot Tanaman}

Data bobot basah dan kering tanaman karet umur enam bulan setelah tanam pada fase pembibitan sebagai respon terhadap pemberian pupuk majemuk Magnesium plus disajikan pada Tabel 6 . Pada perlakuan pupuk majemuk Magnesium plus dosis $125 \%$ mampu meningkatkan bobot basah tanaman tertinggi $(\mathrm{P}<0,05) \quad$ mencapai $200 \%$ dibandingkan kontrol tanpa pupuk tetapi tidak berbeda nyata dengan perlakuan pupuk tunggal NPK + Kieserite standar dan perlakuan pupuk tunggal NPK + Dolomite. Namun, secara kuantitatif bobot basah tanaman cenderung meningkat sejalan dengan penambahan dosis pupuk majemuk Magnesium plus. Pada bobot kering tanaman perlakuan pupuk majemuk Magnesium plus dosis $125 \%$ berpengaruh nyata $(P<0,05)$ mencapai $224 \%$ dibandingkan kontrol tanpa pupuk, tetapi tidak berbeda nyata dibandingkan dengan perlakuan pupuk tunggal NPK + Dolomite dan perlakuan pupuk tunggal NPK + Kieserite standar. Secara kuantitatif pemberian pupuk majemuk Magnesium plus pada semua tingkatan dosis dapat meningkatkan bobot tanaman dibandingkan perlakuan pupuk tunggal NPK + Kieserite standar. Husin, Manurung, dan Khoiri (2014) melaporkan bahwa penambahan pupuk mikro pada pembibitan tanaman kelapa sawit mampu meningkatkan tinggi tanaman, jumlah daun, lilit bonggol, ratio tajuk akar, dan bobot kering.

\section{Bobot Akar}

Perbedaan nyata $(\mathrm{P}<0,05)$ dari bobot basah dan bobot kering akar terlihat pada perlakuan pupuk majemuk Magnesium plus dosis $125 \%$ dibandingkan dengan perlakuan lainnya (Tabel 7). Perlakuan pupuk majemuk Magnesium plus dosis 125\% dapat meningkatkan bobot basah akar tertinggi mencapai $100 \%$ dibandingkan kontrol tanpa pupuk dan $11-22 \%$ di atas perlakuan lainnya. Selain itu, bobot kering akar pada perlakuan pupuk majemuk Magnesium plus dosis $125 \%$ meningkat dengan nilai tertinggi mencapai 99\% dibandingkan kontrol tanpa pupuk dan $41 \%$ lebih tinggi dibandingkan pupuk tunggal NPK+Kieserite standar. Hal ini menunjukkan bahwa pemberian pupuk

Tabel 6. Data bobot tanaman basah dan kering sebagai respon terhadap berbagai perlakuan pupuk majemuk Magnesium plus

Table 6. Wet and dry weights as response to various treatments Magnesium plus compound fertilizer

\begin{tabular}{lcc}
\hline \multicolumn{1}{c}{\begin{tabular}{c} 
Perlakuan \\
\multicolumn{1}{c}{ Treatment }
\end{tabular}} & \multicolumn{2}{c}{$\begin{array}{c}\text { Bobot (g/pohon) } \\
\text { Weight }(g / \text { tree })\end{array}$} \\
\cline { 2 - 3 } & Basah & Kering \\
& Wet & $13,60 \mathrm{a}$ \\
\hline Kontrol, tanpa pupuk & $32,27 \mathrm{a}$ & $31,22 \mathrm{~b}$ \\
Pupuk tunggal NPK + Dolomite & $78,98 \mathrm{ab}$ & $38,21 \mathrm{~b}$ \\
Pupuk tunggal NPK + Kieserite Standar & $95,52 \mathrm{~b}$ & $38,76 \mathrm{~b}$ \\
Pupuk tunggal NPK + pupuk Mg plus 75\% & $98,34 \mathrm{~b}$ & $43,01 \mathrm{~b}$ \\
Pupuk tunggal NPK + pupuk Mg plus 100\% & $105,01 \mathrm{~b}$ & $44,18 \mathrm{~b}$ \\
Pupuk tunggal NPK + pupuk Mg plus 125\% & $106,41 \mathrm{~b}$ & \\
\hline
\end{tabular}

Angka yang diikuti huruf yang sama pada kolom sama menunjukkan tidak berbeda nyata pada taraf $a<$ 0,05

Number followed by the same letter in the same column were not significantly different $a<0.05$ level 
Tabel 7. Data bobot basah dan kering akar sebagai respon terhadap berbagai perlakuan pupuk majemuk Magnesium plus

Table 7. Wet and dry root as response to various treatments Magnesium plus compound fertilizer

\begin{tabular}{lcc}
\hline \multirow{2}{*}{$\begin{array}{c}\text { Perlakuan } \\
\text { Treatment }\end{array}$} & \multicolumn{2}{c}{$\begin{array}{c}\text { Bobot (g/pohon) } \\
\text { Weight }(g / \text { tree })\end{array}$} \\
\cline { 2 - 3 } & $\begin{array}{c}\text { Basah } \\
\text { Wet }\end{array}$ & $\begin{array}{c}\text { Kering } \\
\text { Dry }\end{array}$ \\
\hline Kontrol, tanpa pupuk & $48,46 \mathrm{a}$ & $16,87 \mathrm{a}$ \\
Pupuk tunggal NPK + Dolomite & $63,70 \mathrm{ab}$ & $18,86 \mathrm{a}$ \\
Pupuk tunggal NPK + Kieserite Standar & $80,16 \mathrm{ab}$ & $23,76 \mathrm{ab}$ \\
Pupuk tunggal NPK + pupuk Mg plus 75\% & $81,22 \mathrm{ab}$ & $23,89 \mathrm{ab}$ \\
Pupuk tunggal NPK + pupuk Mg plus 100\% & $87,88 \mathrm{~b}$ & $25,01 \mathrm{ab}$ \\
Pupuk tunggal NPK + pupuk Mg plus 125\% & $97,88 \mathrm{~b}$ & $33,62 \mathrm{~b}$ \\
\hline
\end{tabular}

Angka yang diikuti huruf yang sama pada kolom sama menunjukkan tidak berbeda nyata pada taraf a < 0,05

Number followed by the same letter in the same column were not significantly different a $<0.05$ level

majemuk Magnesium plus pada semua tingkatan dosis mampu meningkatkan bobot kering dan basah akar dibandingkan pupuk tunggal NPK + Kieserite standar. Hasil ini sesuai dengan penelitian Nurjaya (2010) bahwa pemberian pupuk majemuk dapat meningkatkan bobot basah dan bobot kering akar dibandingkan perlakuan pupuk NPK standar dan kontrol.

\section{Nilai Relative Agronomic Effectiveness (RAE)}

Untuk menilai efektivitas pupuk yang diuji dibandingkan dengan pupuk tunggal NPKMg standar, dihitung dengan menggunakan metode RAE (Relative Agronomic Effectiveness). Nilai RAE pupuk magnesium plus pada tanaman karet di pembibitan disajikan pada Tabel 8 .

Nilai RAE dalam hal ini perhitungannya didasarkan pada hasil bobot kering bibit tanaman karet (bobot tanaman dan akar). Hasil analisis menunjukkan bahwa nilai RAE pupuk majemuk Magnesium plus berkisar dari $102-150 \%$ dan secara umum relatif lebih tinggi dibandingkan nilai RAE pada pemupukan pupuk tunggal NPK + Kieserite standar. Pemberian pupuk majemuk Magnesium plus dosis $125 \%$ menghasilkan nilai RAE tertinggi mencapai $150 \%$, menunjukkan bahwa perlakuan ini memiliki efektivitas lebih tinggi 50\% dibandingkan pupuk tunggal NPK + Kieserite standar. Nilai RAE pada perlakuan pupuk majemuk Magnesium plus dosis $75 \%$ juga lebih tinggi $2 \%$ dibandingkan pupuk tunggal NPK + Kieserite standar. Hal ini menunjukkan bahwa pemberian pupuk majemuk Magnesium plus dapat meningkatkan efektivitas pupuk tunggal NPK dalam meningkatkan bobot tanaman karet pada fase pembibitan dibandingkan dengan pemberian pupuk NPK + Kieserite standar saja. Pada perlakuan pemberian pupuk tunggal NPK + Dolomite nilai RAE lebih rendah $40 \%$ dibandingkan pemberian pupuk Kieserite. Sumber $\mathrm{Mg}^{++}$yang paling baik dengan kadar $\mathrm{Mg}^{++}$cukup tinggi adalah Kieserite (27\% MgO). Disamping itu, Kieserite mudah tersedia bagi tanaman. Dolomite adalah sumber $\mathrm{Ca}(30 \%)$ dan $\mathrm{Mg}$ $(19 \%)$ yang cukup baik. Namun, kelarutannya agak rendah dan kualitasnya sangat ditentukan oleh ukuran butir (Kasno \& Nurjaya, 2011).

Berdasarkan hasil penelitian Nurjaya (2010) menunjukkan bahwa pemberian pupuk mikro majemuk pada tanaman karet mampu meningkatkan nilai RAE berkisar dari $100-312 \%$. Unsur hara mikro termasuk unsur hara esensial sehingga harus selalu tersedia bagi tanaman meskipun dibutuhkan oleh tanaman dalam jumlah sedikit. Unsur hara mikro mempunyai fungsi yang spesifik dalam pertumbuhan dan perkembangan tanaman 
Tabel 8. Nilai RAE pupuk majemuk Magnesium plus tanaman karet di pembibitan Table 8. Value RAE Magnesium plus compound fertilizer of rubber plants in nursery

\begin{tabular}{lc}
\hline \multicolumn{1}{c}{$\begin{array}{c}\text { Perlakuan } \\
\text { Treatment }\end{array}$} & $\begin{array}{c}\text { Nilai RAE } \\
\text { Value RAE } \\
(\%)\end{array}$ \\
\hline Kontrol, tanpa pupuk & 0 \\
Pupuk tunggal NPK + Dolomite & 62 \\
Pupuk tunggal NPK + Kieserite Standar & 100 \\
Pupuk tunggal NPK + pupuk Mg plus $75 \%$ & 102 \\
Pupuk tunggal NPK + pupuk Mg plus $100 \%$ & 119 \\
Pupuk tunggal NPK + pupuk Mg plus $125 \%$ & 150 \\
\hline
\end{tabular}

serta fungsinya tidak dapat digantikan secara sempurna oleh unsur hara lain. Karena begitu pentingnya unsur hara mikro selama pertumbuhan dan perkembangan tanaman, walaupun hanya dibutuhkan dalam jumlah sedikit, maka penambahan unsur mikro pada pupuk dilakukan dan dikendalikan lebih teliti dari pada penambahan unsur makro (Sudarmi, 2013).

\section{Kandungan Hara Daun}

Hasil analisa kandungan hara di daun disajikan pada Tabel 9. Kandungan hara $\mathrm{P}$, dan Ca tidak berbeda nyata $(\mathrm{P}>0,05)$ antar perlakuan. Namun kandungan $\mathrm{N}, \mathrm{K}$ dan Mg berbeda nyata $(P<0,05)$. Kandungan
$\mathrm{N}, \mathrm{P}, \mathrm{K}, \mathrm{Ca}$, dan $\mathrm{Mg}$ di daun yang paling rendah dijumpai pada perlakuan kontrol tanpa pemupukan dibandingan dengan perlakuan pemberian pupuk majemuk Magnesium plus. Perlakuan pupuk majemuk Magnesium plus tingkatan dosis $125 \%$ memiliki nilai kandungan hara daun $\mathrm{N}$ tertinggi $(\mathrm{P}<0,05)$ mencapai 2 kali lipat dibandingkan kontrol dan lebih tinggi dibandingkan pupuk tunggal NPK + Kieserite standar. Secara umum pemberian pupuk majemuk Magnesium plus pada semua tingkatan dosis memiliki kandungan hara di daun lebih baik dibandingkan dengan perlakuan kontrol, pupuk tunggal NPK + Kieserite standar dan pupuk tunggal NPK + Dolomite.

Tabe1 9. Kandungan hara N, P, K, Ca, dan Mg di daun

Table 9. Nutrient content in rubber leaf $N, P, K, C a, M g$

\begin{tabular}{lccccc}
\hline \multirow{2}{*}{$\begin{array}{c}\text { Perlakuan } \\
\text { Treatment }\end{array}$} & \multicolumn{5}{c}{$\begin{array}{c}\text { Kadar hara daun } \\
\text { Nutrient content of leaf } \\
\end{array}$} \\
\cline { 2 - 6 } & $\mathrm{N}$ & $\mathrm{P}$ & $\mathrm{K}$ & $\mathrm{Ca}$ & $\mathrm{Mg}$ \\
\hline Kontrol, tanpa pupuk & $2,09 \mathrm{a}$ & $0,12 \mathrm{a}$ & $0,65 \mathrm{a}$ & $0,82 \mathrm{a}$ & $0,15 \mathrm{a}$ \\
Pupuk tunggal NPK + Dolomite & $4,02 \mathrm{~b}$ & $0,16 \mathrm{a}$ & $0,88 \mathrm{~b}$ & $0,87 \mathrm{a}$ & $0,19 \mathrm{ab}$ \\
Pupuk tunggal NPK + Kieserite Standar & $4,18 \mathrm{bc}$ & $0,18 \mathrm{a}$ & $0,86 \mathrm{~b}$ & $1,00 \mathrm{a}$ & $0,20 \mathrm{ab}$ \\
Pupuk tunggal NPK + pupuk Mg plus 75\% & $4,32 \mathrm{c}$ & $0,17 \mathrm{a}$ & $0,93 \mathrm{bc}$ & $0,98 \mathrm{a}$ & $0,20 \mathrm{ab}$ \\
Pupuk tunggal NPK + pupuk Mg plus 100\% & $4,21 \mathrm{bc}$ & $0,18 \mathrm{a}$ & $0,99 \mathrm{c}$ & $1,04 \mathrm{a}$ & $0,25 \mathrm{~b}$ \\
Pupuk tunggal NPK + pupuk Mg plus 125\% & $4,29 \mathrm{c}$ & $0,18 \mathrm{a}$ & $0,99 \mathrm{c}$ & $1,15 \mathrm{a}$ & $0,25 \mathrm{~b}$ \\
\hline
\end{tabular}

Angka yang diikuti huruf yang sama pada kolom sama menunjukkan tidak berbeda nyata pada taraf a < 0,05

Number followed by the same letter in the same column were not significantly different $a<0.05$ level 


\section{KESIMPULAN}

Pemberian pupuk tunggal NPK dikombinasikan dengan pupuk majemuk Magnesium plus dapat meningkatkan pertumbuhan tinggi, diameter batang tanaman dibandingkan dengan perlakuan kontrol tanpa pupuk, pupuk tunggal NPK + Kieserite standar dan pupuk tunggal NPK + Dolomite. Secara agronomis pemberian pupuk majemuk Magnesium plus pada berbagai dosis kombinasi perlakuan efektif meningkatkan bobot tanaman karet selama enam bulan setelah tanam di pembibitan, dibandingkan perlakuan pupuk tunggal $\mathrm{NPK}+$ Kieserite standar dan kontrol tanpa pupuk. Nilai RAE tertinggi mencapai 150\% pada perlakuan pupuk majemuk Magnesium plus dengan tingkatan dosis $125 \%$. Dari segi efisiensi pemupukan, pupuk majemuk Magnesium plus dapat sebagai alternatif pengganti pupuk Kieserite.

\section{DAFTAR PUSTAKA}

Baker, A. V., \& Pilbean, D. J. (2006). Hunger Sign in Crops. In D. J. Merhaut. Handbook of Plants Nutrion (p. 117). Florida, USA: CRC Press.

Boerhendy, I. (2009). Kesejahteraan petani meningkat. All about Natural Rubber Hevea 2 (1). Palembang, Indonesia: Balai Penelitian Sembawa.

Cakmak, I., \& Yazici, A. M. (2010). Magnesium: A forgotten element in crop production. Better Crops, 94(2), 23-25. Diakses dari http://www.kaligmbh.com.

Gransee, A., \& Fuhrs, H. (2013). Magnesium mobility in soils as a challenge for soil and plant analysis, magnesium fertilization and root uptake under adverse growth conditions. Plant Soil, 368(1), 5-21. Doi: 10.1007/s 11104012-1567-y.

Husin, L., Manurung, G. M. E., \& Khoiri, M. A. (2014). Penggunaan pupuk kompos dan pupuk mikro pada pembibitan kelapa sawit (Elaeis Guineensis Jacq.) di medium gambut. Jom Faperta, 1(2), $1-9$.
Kasno, A., \& Nurjaya. (2011). Pengaruh pupuk kieserite terhadap pertumbuhan kelapa sawit dan produktivitas tanah. Jurnal Penelitian Tanaman Industri, 17(4), 133-139.

Machay, A. D., Syers, J. K., \& Gregg, P. E. H. (1984). Ability of Chemical extraction procedures to asses the agronomic effectiveness of phosphate rock materials. New Zealand Jounal of Agriculture Research, 27(2), 219-230.

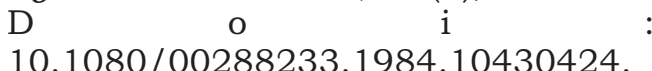

Maulana, I. (2012). Pengaruh variasi Dolomite material lokal Kabupaten Bangkalan sebagai subsitusi agregat dalam pembuatan batako terhadap kuat tekan dan absorbsi. Jurnal Teknik Sipil, 1(3), 1-4.

Meihana., \& Rusidi. (2013). Pemanfaatan limbah media jamur tiram sebagai bahan pencampur tanah dan dosis pupuk NPK majemuk bagi pertumbuhan bibit karet stum mata tidur (Hevea brasiliensis Muell Arg.) di polybag. Jurnal Ilmiah AgrIBA, 2, 225236.

Nugroho, P. A. (2009). Rekomendasi pemupukan tanaman karet di Malaysia. Warta Perkaretan, 28(1), 2841.

Nurjaya, (2010). Respon tanaman karet di pembibitan terhadap pemberian pupuk mikro majemuk. Prosiding Seminar Nasional Sumberdaya Lahan Pertanian (p. 195-208). Bogor, Indonesia: Kementerian Pertanian.

Pusat Penelitian Tanah. (1983). Kriteria Sifat Kimia Tanah. Bogor, Indonesia: Departemen Pertanian.

Reuther, W. (1957). Copper and soil fertility. In A. Stefferud. The Yearbook of Agriculture. (p. 128-135). Washington DC, USA: USDA.

Sianipar, S. S. E., Saputra, S. I., \& Puspita, F. (2014). Uji beberapa dosis pupuk hayati mikoriza terhadap pertumbuhan stum mini karet (Hevea brasiliensis). Jom Faperta, 1(2), 1-11. 
Stevanus, C. T., Saputra, J., \& Wijaya, T. (2015). Peran unsur mikro bagi tanaman karet. Warta Perkaretan, 34(1), 11-18.

Sudarmi. (2013). Pentingnya unsur hara mikro bagi pertumbuhan Tanaman. Widyatama, 2(22), 178-183.

Suwandi. (2008). Aplikasi dolomite dan urea terhadap pertumbuhan murbei (Morus khunpai). Info Hutan, V(4), 377-385.

Tuteja, N., \& Mahajan, S. (2007). Further characterization of calsineurin B-like protein and its interacting partner CBL-interacting protein kinase from Pisum sativum. Plant Signal Behav, $2(5), \quad 358-361$. D o i : $10.4161 /$ psb.2.5.4178.
Wachjar, A., \& Kadarisman, L. (2007). Pengaruh kombinasi pupuk organik cair dan pupuk anorganik serta frekuensinya terhadap pertumbuhan tanaman kakao (Theobrama cacao L.) belum menghasilkan. Bul. Agron., 35, 212216.

Yang, G. H., Yang, L. T., Jiang, H. X., Li, Y., Wang, P., \& Chen, L. S. (2012). Physiological impacts of magnesium -defisiency in Citrus seedlings: photosynthesis, antioxidant, system and carbohydrates. Trees, 26, 1237 1250. Doi: 10.1007/S00468-0120699-2. 